\title{
Studi Redesain Pasar Kangkung Teluk Betung (Tema : Arsitektur Modern Tropis)
}

\author{
Rivena Elbes ${ }^{1}$ \\ ${ }^{1}$ Arsitek, PT Anugerah Pesona Kreasi \\ *Penulis Korespondensi: Rivenaelbes76@gmail.com
}

\begin{abstract}
Abstrak:
Pasar Kangkung merupakan sebuah pasar tradisional yang cukup dikenal di wilayah Teluk Betung. Pasar Kangkung menjadi tujuan yang cukup diperhitungkan oleh masyarakat dalam memenuhi kebutuhan sehari-hari. Seiring berjalannya waktu dan berkembangnya gaya hidup masyarakat, pasar tradisional mulai kehilangan citranya. Pasar tradisional yang tidak mengikuti perkembangan jaman lama-kelamaan mulai ditinggalkan. Masyarakat memiliki banyak pilihan tempat untuk memenuhi kebutuhan sehari-harinya dengan cara yang lebih instan dan praktis. Misalnya dengan berbelanja online, atau pergi ke minimarket yang sekarang menjamur keberadaannya yaitu hanya dalam beberapa radius meter saja. Sebagai pasar tradisional yang dapat dikatakan merupakan citra masyarakat Teluk Betung ini, pasar kangkung diharapkan dapat bertahan dari pertumbuhan dan persaingan pasar-pasar modern. Oleh sebab itu penulis berkeinginan untuk meredesain pasar kangkung dengan pendekatan Arsitektur modern tropis. Dengan menggunakan pendekatan ini diharapkan Pasar Kangkung dapat mengikuti perkembangan jaman dan tidak kalah saing dengan pasar modern dan terus menarik minat pembeli untuk datang ke pasar. Penulis juga berharap agar dapat terus mendukung keberlangsungan pasar tradisional yang telah banyak berkontribusi terhadap perekonomian masyarakat teluk betung ini.
\end{abstract}

Kata Kunci: Pasar; tradisional; arsitektur; modern

\section{Latar Belakang}

Pasar tradisional merupakan salah satu sumber kegiatan ekonomi yang dapat diandalkan (Agustina, 2009). Sektor perdagangan memiliki ciri khas tersendiri yaitu adanya pola interaksi antara penjual dan pembeli saat tawar menawar barang dagangan, tidak hanya sebagai tempat aktivitas penjual dan pembeli melainkan juga sebagai tempat berkumpulnya berbagai suku dan agama, dalam perkembangannya pasar tradisional juga sebagai media wisata belanja, edukasi, serta meningkatkan pendapatan pedagang mikro.

Pasar Tradisional merupakan salah satu pilar perekonomian di negeri ini. Alur perputaran uang sangatlah cepat. Selain karena proses tawar menawar, dengan adanya informasi yang cepat menyebar lewat mulut ke mulut juga dapat menjadi pendukung bagi penjual untuk mendapatkan konsumen. Tidak hanya itu, Pasar Tradisional dapat menampung banyak pedagang yang cukup untuk mengurangi angka pengangguran. Namun dalam perkembangannya, pasar tradisional mulai bertrasnsformasi menjadi pasar modern (Adianti, 2016). Hal ini disebabkan adanya kebutuhan masyarakat yang menginginkan pasar yang berbeda dari biasanya.

Arsitektur Modern bentuk mengikuti fungsi (form follows function) yang dicetuskan oleh pemahat Horatio Greenough atau yang lebih dikenal sebagai Louis Sullivan. Sedikit adalah lebih (Less is More) diumumkan oleh arsitek Mies van der Rohe. Sedikit adalah lebih dan lebih adalah banyak (Less is More and More only when More is Too Much) yang diungkapkan oleh Frank Llyod Wright. Dalam Arsitektur Modern, gaya hidup modern berimbas kepada keinginan untuk memiliki bangunan yang simple, bersih dan fungsional, sebagai simbol dari semangat modern. Namun, gaya hidup semacam ini hanya dimiliki oleh sebagian masyarakat saja, terutama yang berada di kota besar, dimana kehidupan menuntut gaya hidup yang lebih cepat, fungsional dan efisien.

Arsitektur Tropis kondisi iklim tropis memerlukan syarat-syarat khusus dalam perancangan bangunan dan lingkungan binaan, mengingat ada beberapa faktor-faktor spesifik yang hanya dijumpai secara khusus pada iklim tersebut, sehingga teori-teori Arsitektur, komposisi, bentuk, fungsi bangunan, citra bangunan dan nilai-nilai estetika bangunan yang terbentuk akan sangat berbeda dengan kondisi yang ada di wilayah lain yang berbeda kondisi iklimnya.

Arsitektur Tropis adalah suatu konsep bangunan yang mengadaptasi kondisi iklim tropis. Letak geografis Indonesia yang berada di garis khatulistiwa membuat Indonesia memiliki dua iklim, yaitu kemarau dan penghujan. Pada musim kemarau suhu udara sangat tinggi dan sinar matahari memancar sangat panas. Dalam kondisi ikim yang panas inilah muncul ide untuk menyesuaikannya dengan Arsitektur bangunan gedung maupun rumah yang dapat memberikan kenyamanan bagi penghuninya. 


\section{Metode}

Penelitian ini menggunakan metode penelitian deskriptif kualitatif. Penelitian kualitatif dilakukan karena peneliti ingin mengeksplor fenomena-fenomena yang tidak dapat dikuantifikasikan yang bersifat deskriptif seperti proses suatu langkah kerja, formula suatu resep, pengertian-pengertian tentang suatu konsep yang beragam, karakteristik suatu barang dan jasa, gambar- gambar, gaya- gaya, tata cara suatu budaya, model fisik suatu artifak dan lain sebagainya.

\subsection{Metode Pengumpulan Data}

Data adalah bagian terpenting dari suatu penelitian, karena dengan data peneliti dapat mengetahui hasil dari penelitian tersebut. Pada penelitian ini, data diperoleh dari berbagai sumber, dengan menggunakan teknik pengumpulan data yang bermacam- macam dan dilakukan secara terus menerus sampai datanya jenuh. Sesuai dengan karakteristik data yang diperlukan dalam penelitian ini, maka teknik pengumpulan data yang dilakukan berupa observasi dan dokumentasi. Observasi dilakukan pada obyek penelitian sebagai sumber data dalam keadaan asli atau sebagaimana keadaan sehari-hari. Sedangkan, dokumentasi dilakukan penulis adalah berdasarkan foto yang penulis kumpulkan.

\subsection{Metode Analisis Data}

\section{Studi Literatur}

Dilakukan dengan cara mempelajari, membaca, mencatat, memahami dan mengutip data-data yang diperoleh dari beberapa literatur berupa buku, peraturan, laporan, internet dan dokumen-dokumen yang berkaitan dengan pokok bahasan pada laporan seminar ini.

\section{Hasil dan Pembahasan}

\subsection{Karakteristik dan Kegiatan di Lingkungan Tapak}

Tapak Pasar Kangkung terpilih merupakan tapak yang digunakan bangunan pasar kangkung lama dengan penambahan luasan lahan. Tapak terletak di jalan Ikan Pari, Teluk Betung Selatam, Bandar Lampung. Kriteria yang dipertimbangkan untuk tetap memilih tapak ini adalah sebagai berikut:

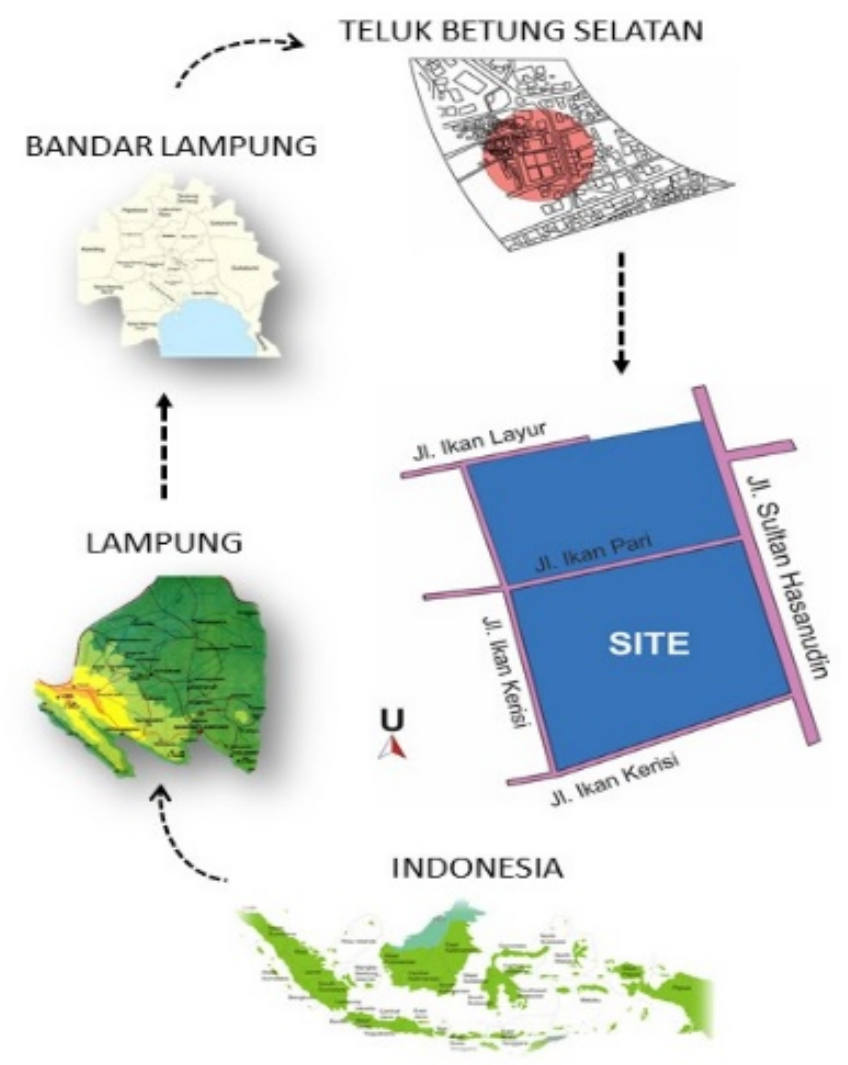

Gambar 1. Lokasi Site 
1. Terletak di jalan yang menghubungkan, jalan protokol jalan Hasanudin, jalan Laks. Malahayati, serta jalan-jalan kecil yang merupakan akses jalan yang ramai dilalui masyarakat sekitar. Selain itu daerah tersebut merupakan kawasan perdagangan dan permukiman berkepadatan tinggi.

2. Pencapaian menuju lokasi yang mudah, banyaknya moda transportasi umum yang melewati tapak ini. Baik kendaraan mobil umum, ojek, bahkan becak.

3. Tapak relatif datar, berpotensi untuk pengembangan lahan.

3.2. Rona Lingkungan Hidup

1) Komponen Geografi

-Keadaan tanah/topografi

Keadaan tanah pada lokasi site Pasar Kangkung memiliki kontur tanah yang realtif datar yaitu dengan kontur \pm 0.00 sampai $0.30 \mathrm{~m}$.

-Cuaca

Negara indonesia memiliki dua musim yaitu musim panas dan musim hujan. Musim panas sangat berpengaruh pada tata letak dan orientasi masa bangunan. Sedangkan arah angin berpengaruh sebagai acuan untuk mengetahui dimana bukaan-bukaan akan diletakkan.

\section{2) Komponen Biotik}

-Flora (Vegetasi)

Vegetasi yang terdapat dalam site antara lain:

Pohon buah kedondong yang berada di depan pasar

-Fauna

Fauna seringkali ditentukan lebih banyak oleh tipe/jenis makanan dan tempat berlindung yang mampu diberikan oleh vegetasi, faktor-faktor fisik lainnya, karena hewan dapat berpindah dari satu tempat ketempat lainnya sembarang waktu. Dalam kondisi site Pasar Kangkung tidak banyak terdapat tumbuhan sebagai tempat berlindung maupun habitat para hewan. Oleh karena itu tidak terdapat habitat hewan tertentu di dalam site.

-Manusia

Dalam perencanaan pada suatu kawasan atau lahan akan mempengaruhi baik buruknya terhadap perekonomian lingkungan sekitar, maka perlu adanya pertimbangan-pertimbangan berdasarkan perekonomian lingkungan setempat. Berdasarkan data yang diperoleh dari lokasi lahan terdapat dua kelompak pemukiman warga yaitu di sebelah selatan site dan sebelah barat site.

\subsection{Klimatologi}

Indonesia terletak pada iklim tropis dengan dua musim yaitu kemarau dan hujan. Pada kedua musim ini bangunan sebaiknya memiliki respon yang baik agar beradaptasi terhadap kedua musim tersebut. Untuk beradaptasi dengan musim dan intensitas cahaya matahari dapat dilakukan dengan memberikan tritisan pada bangunan serta kemiringan atap yang sesuai.

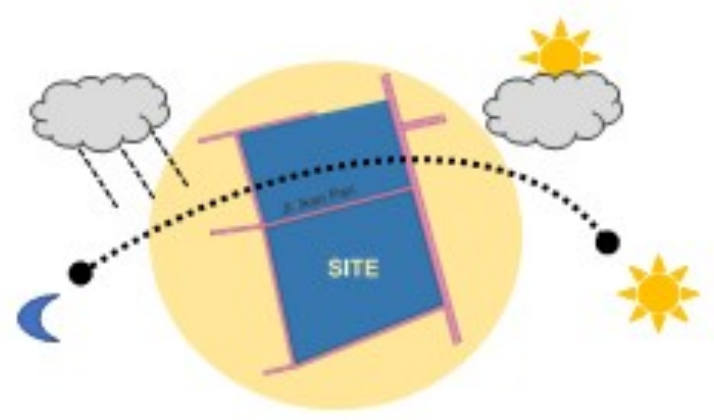

Gambar 2. Analisa Matahari dan Cuaca

Indonesia terletak pada iklim tropis dengan hembusan angin yang cukup kencang. Pada keadaan angin yang cukup kencang bangunan sebaiknya memiliki respon yang baik agar beradaptasi dengan keadaan tersebut. Angin pada tapak berhembus dari arah depan bangunan (utara) ke arah belakang bangunan (selatan). Keadaan ini dapat diselesaikan dengan solusi antara lain:

1. Penggunaan kisi-kisi pada jendela dapat menjadi alternatif desain.

2. Penanaman tumbuhan sebagai pemecah dan penahan laju angin. 


\subsection{Utilitas Lingkungan}

1. Air Bersih

Berdasarkan perolehan data dan informasi untuk melayani kebutuhan air yaitu dengan pemanfaatan air PAM.

2. Drainase

Sistem drainase saat ini yaitu saluran yang dibuat di beberapa titik yang kemudian menuju satu saluran pembuangan. 3. Persampahan

Sampah-sampah dari setiap kios setiap hari dikumpulkan ke tempat pembuangan yang ada di pasar. Kemudian pada sore hari sampah-sampah tersebut dibawa ke TPA.

4. Jaringan Listrik

Jaringan lisrik berasal dari saluran listrik PLN.

\subsection{Pencapaian dan Sirkulasi Tapak}

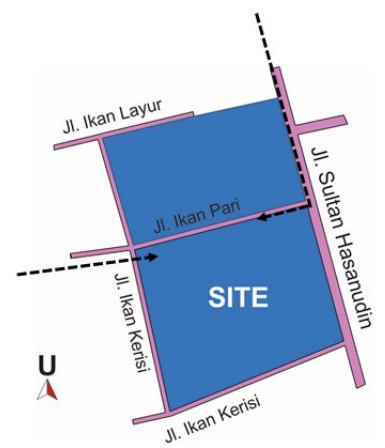

Gambar 3. Pencapaian \& Sirkulasi Tapak

Tapak dapat dicapai dari dua arah yaitu utara dan barat. Dari arah utara pencapaian melalui Jalan Sultan Hasanudin, jalan ini merupakan jalan yang banyak dilalui transportasi umum. Dari arah barat pencapaian melalui Jalan Ikan Pari, jalan ini merupakan jalan ditengah pemukiman yang padat penduduk. Lokasi tapak cukup strategis sehingga sangat memudahkan dalam pencapaian tapak. Namun untuk sirkulasi pencapaian akses kurang nyaman dikarenakan sering terjadi kemacetan.

\subsection{Orientasi Bangunan}

View dari dalam bangunan akan menentukan besaran dan jenis bukaan pada bangunan. Untuk dapat memaksimalkan fungsi bukaan sebagai pengarah atau view. Maka, perlu mempertimbangkan potensi lingkungan disekitar tapak serta orientasi matahari.

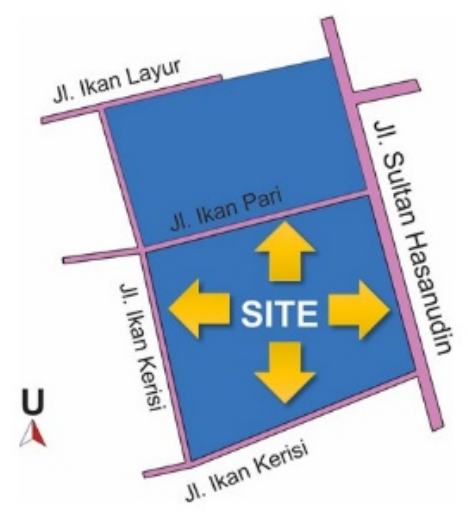

Gambar 4. Orientasi Bangunan

1. Arah Utara, orientasi bangunan menghadap Jalan Ikan Pari yang merupakan jalan pertemuan dari arah jalan Sultan Hasanudin dan Jalan Ikan Kerisi. View pada arah ini akan terlihat sangat padat dan cenderung terjadi kemacetan kendaraan.

2. Arah Timur, orientasi bangunan menghadap Jalan Sultan Hasanudin yang merupakan jalan protokol. Lebar jalan ini cukup lebar dan selalu ramai lalu lintas kendaraan. View pada arah ini cenderung tertutup pertokoan yang berada sepanjang Jalan Sultan Hasanudin. 
3. Arah Selatan, orientasi bangunan menghadap Jalan Ikan Kerisi yang merupakan jalan pertemuan antara pemukiman warga dan Jalan Hasanudin. View pada arah ini akan terlihat pemukiman warga serta pertokoan kecil. 4. Arah Barat, orientasi bangunan menghadap Jalan Ikan Kerisi yang merupakan jalan yang diapit site dan pemukiman warga. View pada arah ini akan terlihat pemukiman warga yang cukup padat.

\subsection{Tata Ruang Luar}

Analisa tata luar bertujuan untuk mengetahui letak tata ruang disekitar site, analisis ruang luar ini berguna untuk menentukan sikap tata ruang dalam site terhadap tata ruang luar site.

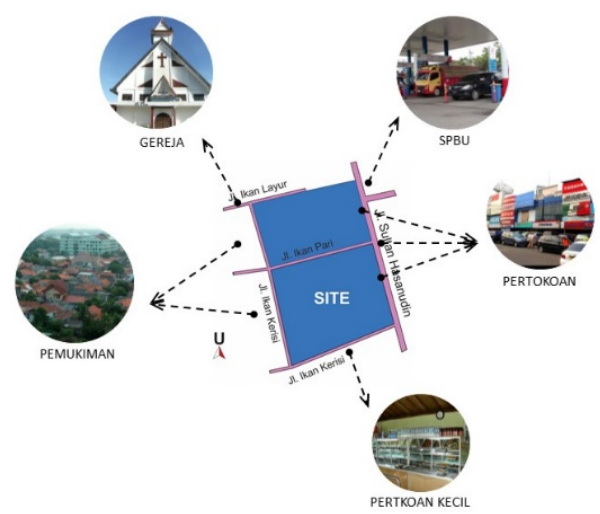

Gambar 5. Tata Ruang Luar

\subsection{Aspek Manusia}

Melalui analisa yang dilakukan terdapat lima pelaku kegiatan di sebuah bangunan pasar yaitu pedagang, pembeli, pengelola, petugas servis, dan pengunjung. Seperti pada pengertian sebelumnya, pasar adalah tempat bertemunya penjual dan pembeli untuk melakukan aktivitas jual beli. Pedagang dan pembeli merupakan pengguna utama, yaitu mereka yang melakukan aktivitas jual beli didalam sebuah bangunan pasar. Sedangkan pengelola, petugas servis, dan pengunjung merupakan pengguna pendukung.

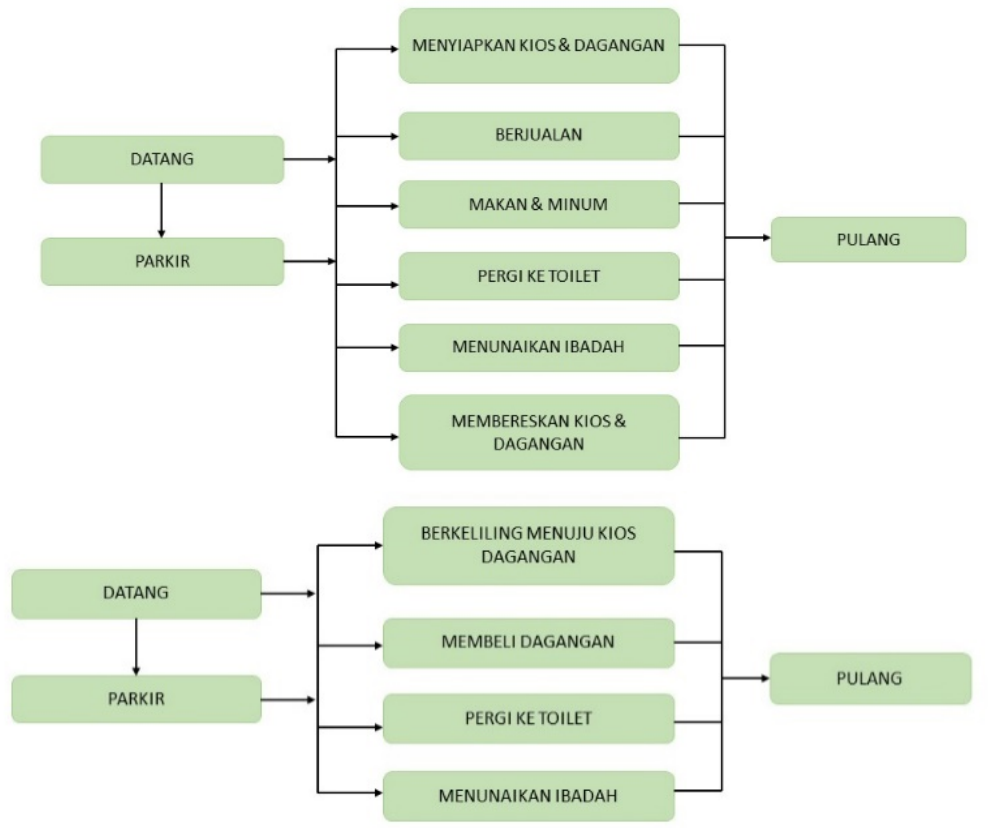

Gambar 6. Diagram Aktivitas

\subsection{Aspek Bangunan}

\section{Kebutuhan Ruang}

Kebutuhan ruang dibuat untuk menetapkan macam fungsi ruang yang dibutuhkan untuk memenuhi tuntutan dan kebutuhan pengguna (Neufert, 1996).

Besaran Ruang 
Analisa kebutuhan ruang dibuat dengan tujuan untuk mengetahui seberapa besar luas lahan yang dibutuhkan oleh kelompok-kelompok aktivitas yang direncanakan agar dapat berfungsi dan berjalan dengan baik (Neufert, 1996).

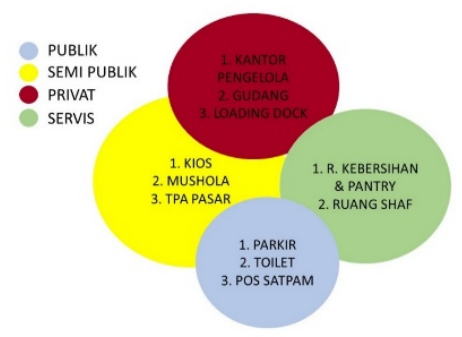

Gambar 7. Program Ruang

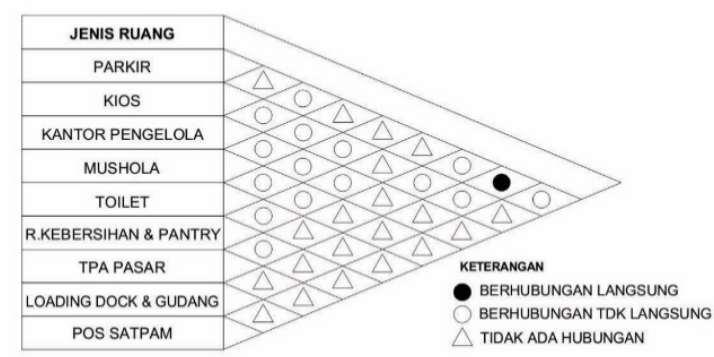

Gambar 8. Matriks Ruang

3.10. Konsep dan Perancangan

3.10.1. Konsep Tapak

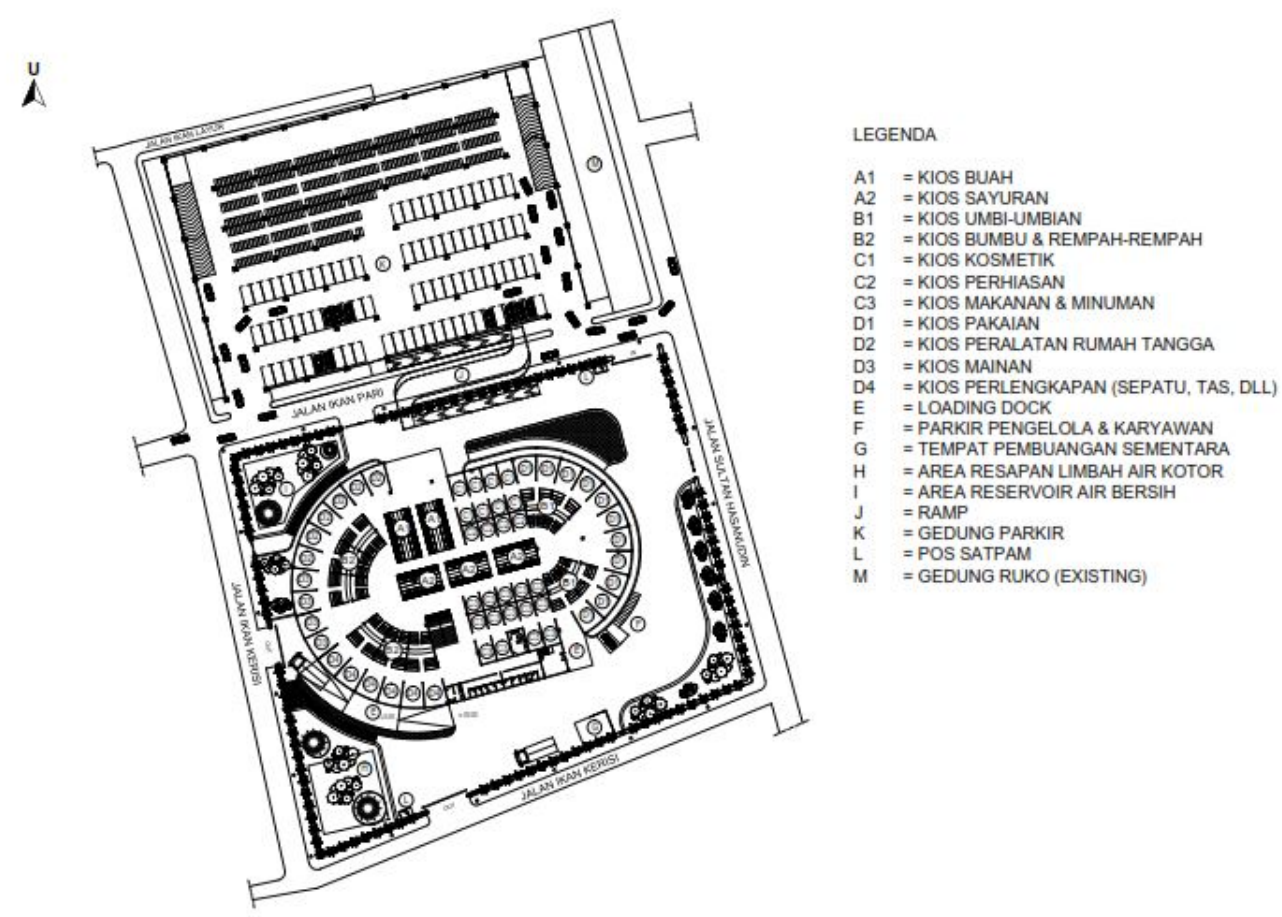

Gambar 9. Site Plan

Untuk sirkulasi parkir dan kegiatan loading barang memiliki waktu tertentu, hal tersebut berdasarkan dari studi aktivitas dari pasar itu sendiri, aktivitas tersebut berdasar dari waktu kegiatan yaitu: 


\section{Loading Dock}

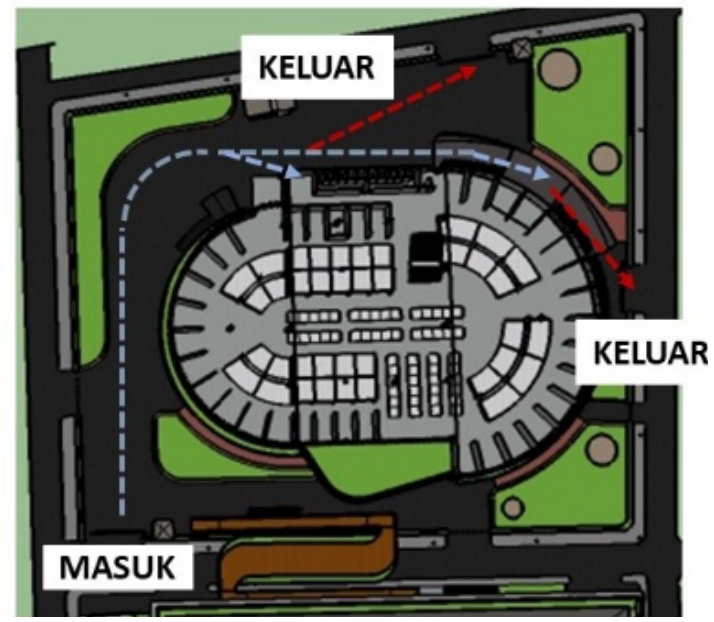

Gambar 10. Sirkulasi Loading Dock

Kegiatan Loading Dock berlangsung pada lokasi tertentu, dimana proses tersebut berada diareanya yang langsung pada bangunan pasar utama agar mempercepat proses pembongkaran tersebut. Pembongkaran dilakukan pada dua lokasi yaitu lantai satu dan lantai dua. Pada lantai dua, mobil bongkar muat akan menaiki ramp dan keluar pada akses keluar di samping bangunan. Sedangkan pada lantai satu akses keluar berada di belakang bangunan.

\section{Parkir Umum}

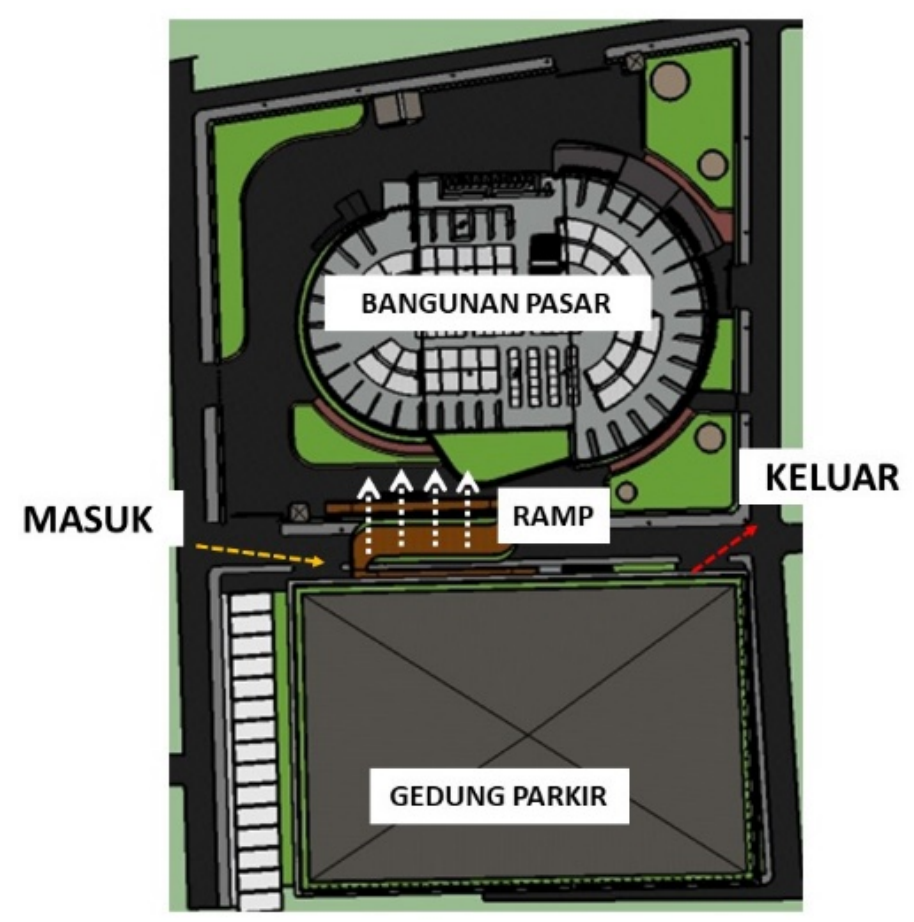

Gambar 11. Parkir Umum

Untuk sirkulasi parkir umum ada dua yaitu mobil dan sepeda motor, dimana aktivitas ini berlangsung selama jam operasional pasar. Parkir umum terpisah dari bangunan pasar utama yaitu terletak disebrang bangunan utama. Gedung parkir memiliki keterikatan dengan bangunan utama yaitu sebuah ramp yang menghubungkan antara gedung parkir dan bangunan pasar. Para pembeli yang membawa kendaraan dapat mencapai pasar melalui ramp sehingga tidak perlu menyebrang jalan. Ramp dibuat dengan pertimbangan untuk keselamatan penyebrang jalan dan mengurangi kemacetan jika para pembeli beramai-ramai menyebrang jalan. 


\section{Parkir Pengelola}

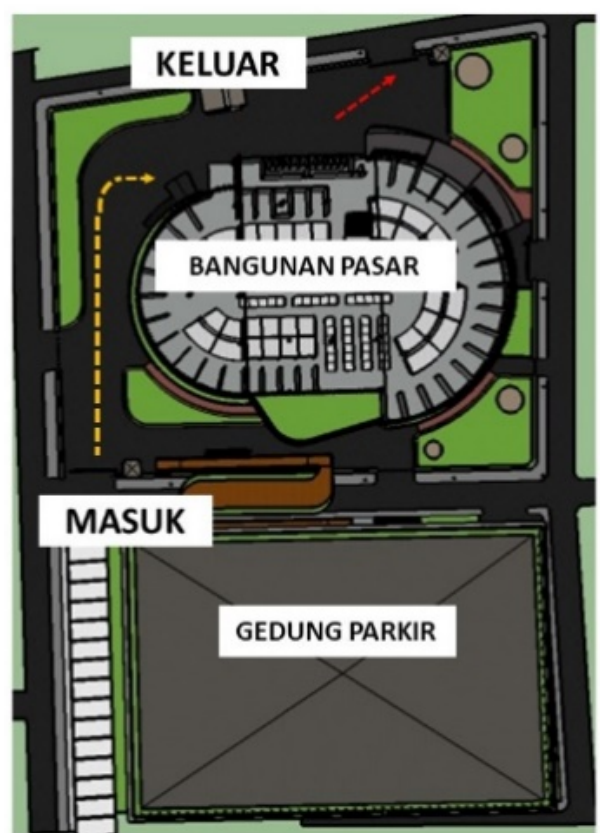

Gambar 12. Parkir Pengelola

Sirkulasi parkir pengelola dan para staff ada dua yaitu mobil dan sepeda motor. Parkir pengelola dan staff berada pada bangunan pasar utama yaitu letaknya dibagian belakang bangunan pasar. Parkir pengelola berada pada bangunan utama untuk mempermudah akses pengelola dan para staff ke bangunan utama.

\subsubsection{Konsep Bangunan}

1. View dan Orientasi Bangunan

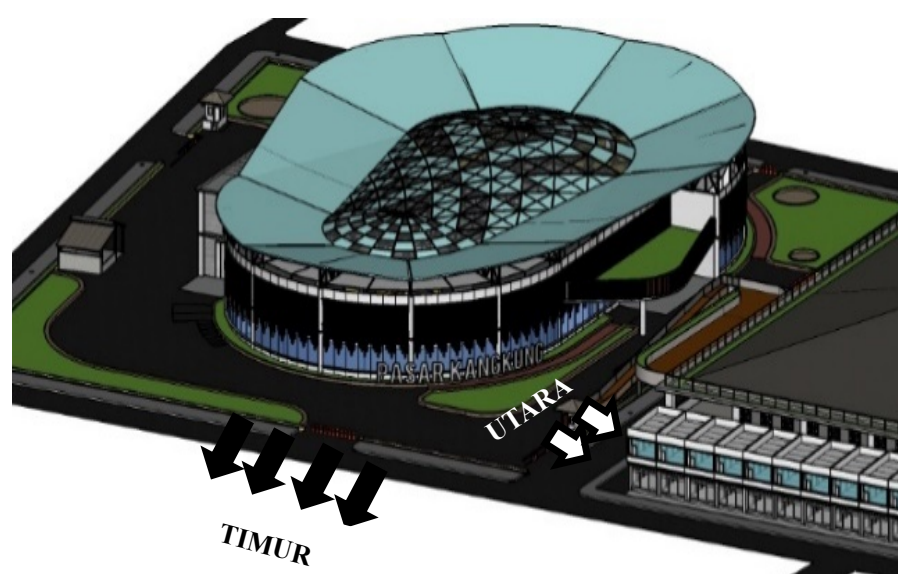

Gambar 13. View \& Orientasi Bangunan

View dan orientasi bangunan pada site ini yaitu pada sisi timur dan utara site. Sisi timur site sebagai titik view bangunan karena tidak adanya penghalang view di sisi tersebut. Dari sisi timur yaitu Jalan Sultan Hasanudin bagunan dapat terlihat jelas dan menarik pandangan ketika melewati Jalan Sultan Hasanudin. 


\section{Massa Bangunan}
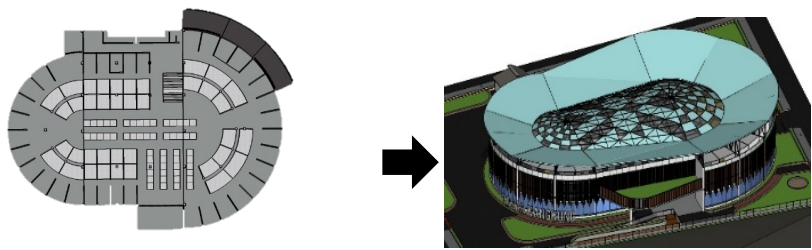

Gambar 14. Bentuk \& Massa Bangunan

Konsep massa bangunan dari perancangan pasar ini adalah dengan menganalisa kebutuhan ruang dan fasilitas dari pasar itu sendiri. Bentuk massa bangunan diperoleh dari kebutuhan ruang / denah bangunan yang terlebih dahulu dibuat. Tema perancangan pasar ini yaitu modern tropis. Salah satu teori Arsitektur modern yang dikenal pada abad 20an yaitu form follow function (bentuk mengikuti fungsi). Paradigma "Form follow Function" atau bentuk mengikuti fungsi, pertama kali diperkenalkan oleh Louis Sullivan. Ia mengatakan bahwa bentuk adalah akibat dari perwadahan fungsi, suatu konsekuensi terstruktur dari hadirnya fungsi yang merupakan gambar dari kegiatan dimana kegiatan tersebut membutuhkan ruang untuk keberlangsungannya. Sullivan berpendapat bahwa bentuk mengikuti fungsi adalah suatu hukum alam.

\section{Penerapan Kaidah Arsitektur Tropis}

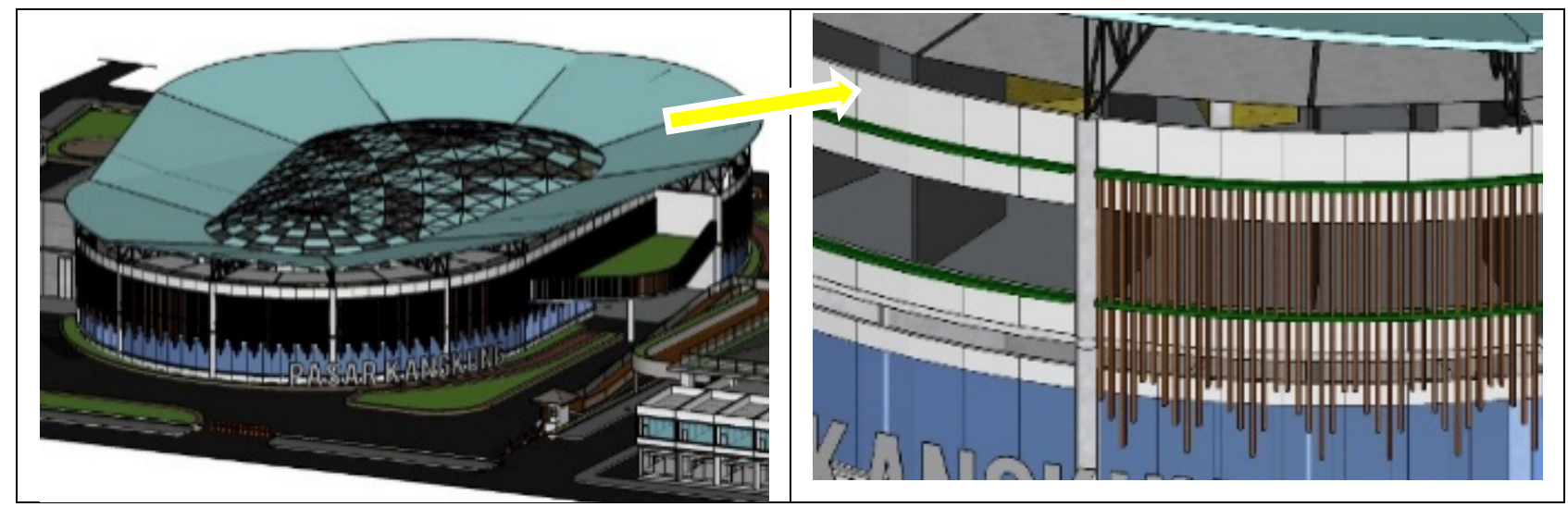

Gambar 15. Kisi-kisi Pada Fasad Bangunan

Prinsip perancangan bangunan pada daerah beriklim tropis yang benar harus mempertimbangkan pemanfaatan sebanyak mungkin kondisi alam, Diantaranya adalah pengupayaan pemikiran penghawaan alami untuk memenuhi kebutuhan udara, kelancaran sirkulasi udara pada bangunan, serta pemar satan cahaya matahari secara maksimal.

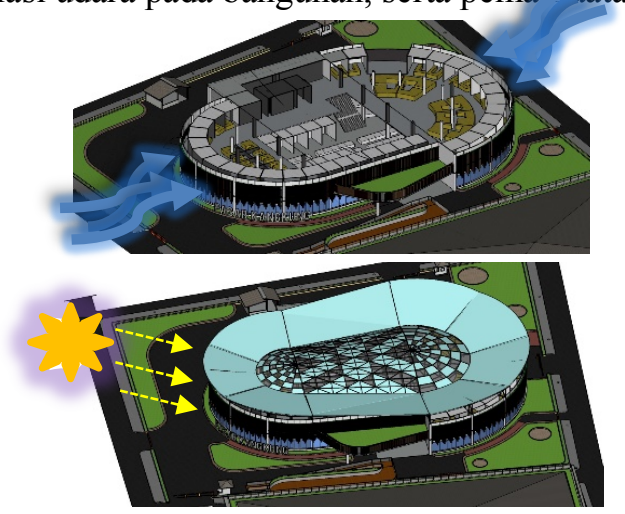

Gambar 16. Rencana Tanggap Lingkungan 
Fungsi utama kisi-kisi kayu yang diterapkan pada bangunan pasar sebagai penghalau sinar matahari langsung yang terpapar di sisi timur bangunan. Selain tanaman sebagai penahan sinar matahari, kisi-kisi juga diharapkan dapat menjadi sun shading yang optimal pada sisi timur bangunan.

Fungsi lain dari kisi-kisi tersebut antara lain sebagai sumber penghawaan alami dan kelancaran sirkulasi udara didalam bangunan. Dalam upaya pemanfaatan penghawaan alami, perlu diperhatikan bahwa pengaliran udara yang perlahan-lahan namun kontinyu sangat mutlak diperlukan, agar udara didalam ruangan selalu diganti dengan udara yang bersih, sehat, segar dan terasa nyaman. Kelancaran aliran/ sirkulasi udara pada suatu susunan ruang bisa diperoleh dengan membuat lubang-lubang ventilasi pada bidang-bidang yang saling berseberangan (cross ventilation).

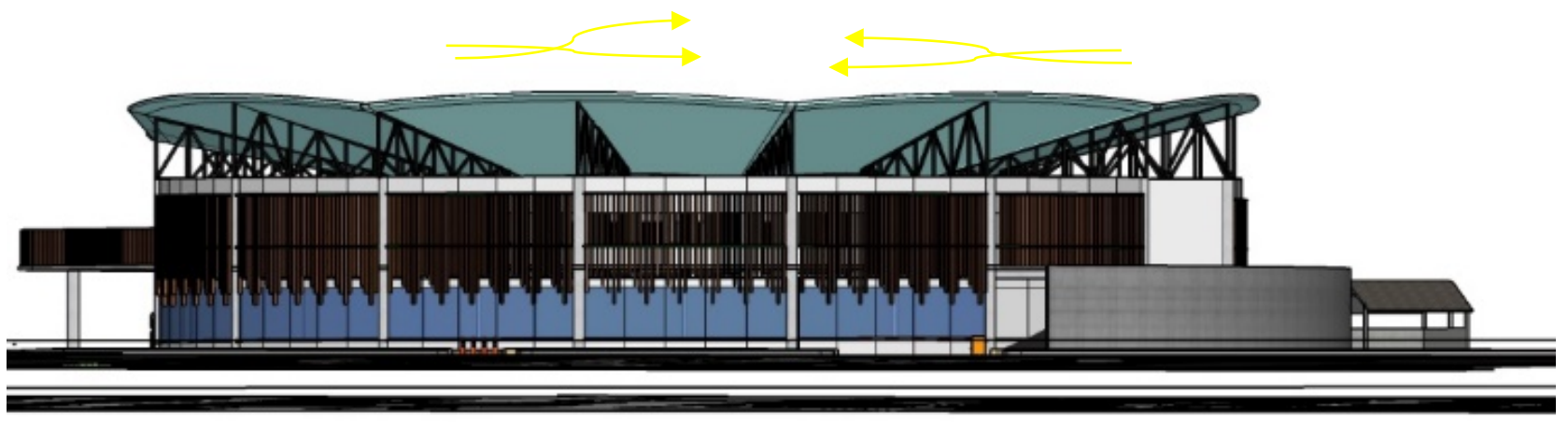

Gambar 17. Sirkulasi Aliran Udara Vertikal

Pelubangan pada langit-langit, memungkinkan udara kotor dan kering bisa menerobos keluar ruangan secara Vertikal. Penerapan "skylight", yaitu upaya memanfaatkan sinar matahari dengan sistem pencahayaan dari atap, yang dikombinasikan dengan lubang-lubang ventilasi Vertikal pada daerah tersebut, dengan demikian panas akibat adanya radiasi sinar matahari dari skylight bisa berfungsi sebagai penyedot udara, hal ini disebabkan didaerah tersebut terjadi tekanan udara rendah akibat timbulnya kenaikan suhu udara. Karena udara akan mengalir dari daerah dengan suhu rendah (yang mempunyai tekanan tinggi) kedaerah dengan suhu tinggi (yang mempunyai tekanan rendah).

\section{Sirkulasi Bangunan}

a. Sirkulasi Horisontal

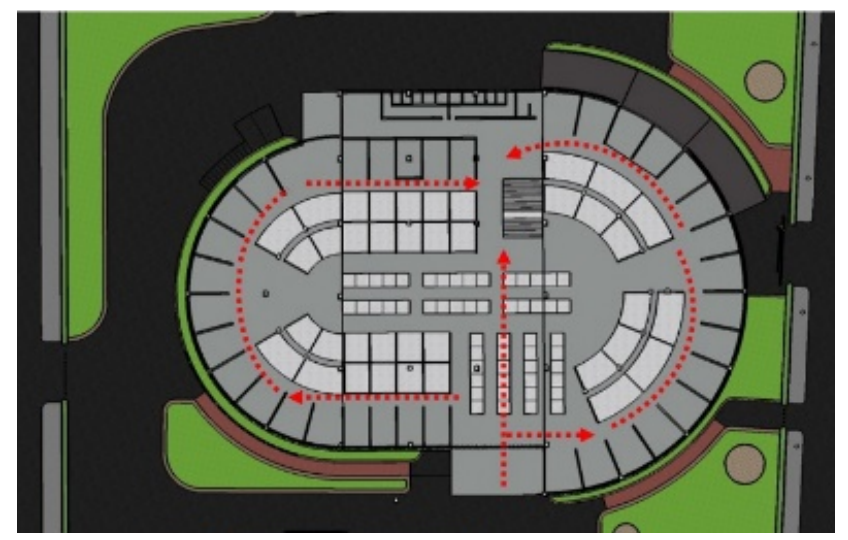

Gambar 18. Sirkulasi Horisontal

Untuk mencapai kios-kios dan ruangan pendukung lain didalam bangunan pengguna dapat mengkuti alur sirkulasi yang terbentuk seperti pada gambar diatas. Ruang-ruang berpola radial sehingga alur sirkulasi pengguna mengalir mengikuti koridor-koridor yang terbentuk secara radial.

b. Sirkulasi Vertikal 


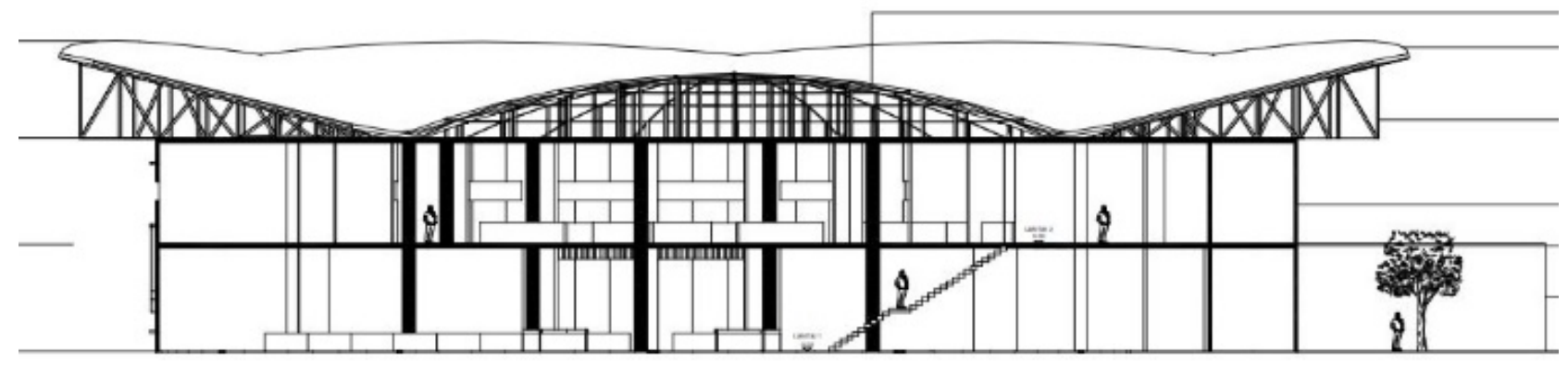

Gambar 17. Sirkulasi Vertikal

Sirkulasi Vertikal pada bangunan pasar ini menggunakan akses tangga untuk sirkulasi perlantai yang menghubungkan lantai satu dengan lantai dua.

\section{Sistem Struktur dan Modul Struktur Bangunan}

a. Sistem Struktur

Untuk mendapatkan hasil perancangan yang ideal sistem struktur bangunan ini terdiri dari tiga bagian, yaitu struktur atap, struktur utama, dan struktur pondasi. Penggunaan ketiga elemen struktur ini diharapkan dapat membentuk ruang yang maksimal penggunaanya. Sistem struktur yang akan diaplikasikan pada bangunan yaitu berupa sistem rangka beton bertulang. Sistem rangka ini disebut juga dengan rangka kaku karena prinsip dari struktur ini adalah kekakuan sambungan-sambungan betonnya.

\section{b. Sistem Modul}

Modul struktur yang digunakan yaitu modul struktur grid dan radial. Modul struktur grid sangat efesien dalam pemanfaatan ruang pada bangunan. Dan modul struktur radial digunakan karena terdapat bentuk ruang dengan denah berpola lingkaran. Berikut modul struktur yang akan digunakan pada bangunan:

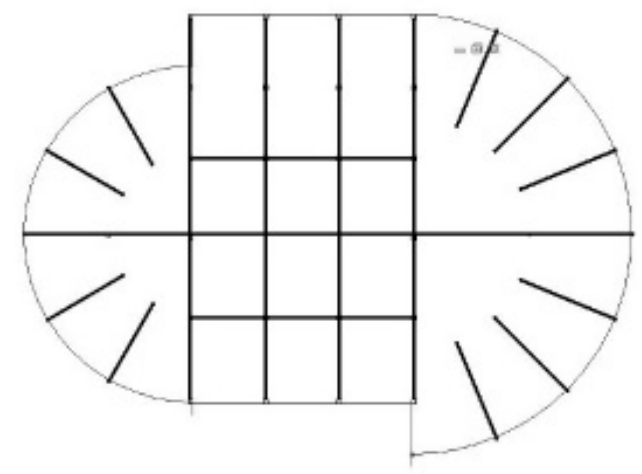

Gambar 18. Modul Struktur

6. Utilitas Bangunan

a. Penyedia Air Bersih

Kebutuhan air bersih bagi penghuni direncanakan akan menggunakan sumber air PDAM dan sumur dalam (deep well), agar tidak mengganggu sumur dangkal milik penduduk sekitar. Sistem penyediaan air bersih menggunakan sistem tangki atap (down feed system). Dalam sistem ini air ditampung terlebih dahulu di dalam tangki bawah (ground reservoir), selanjutnya dipompakan dengan pompa transfer melalui pipa-pipa saluran air bersih.

Perencanaan konsep rainwater system juga dilakukan pada bangunan. Sistem rainwater berasal dari air hujan yang turun melalui talang di atap bangunan kemudian disalurkan melalui pipa air hujan dan selanjutnya masuk kedalam tangki penampung air hujan. Air hujan yang telah ditampung selanjutnya digunakan untuk menyiram area hijau disekitar bangunan. 


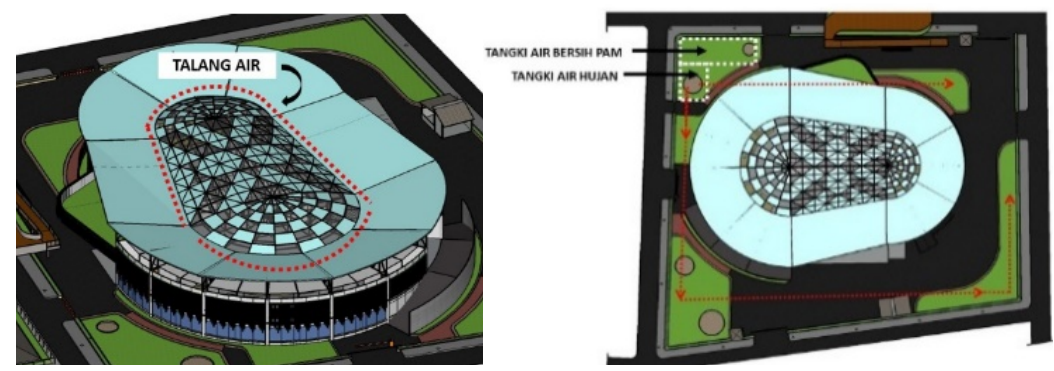

Gambar 19. Penampung dan Aliran Air Hujan

\section{b. Pengolahan Air Kotor Sebelum ke Pembuangan}

Pengelolahan air limbah yang diterapkan yaitu penyaringan agar tidak mencemari lingkungan. Sistem kerja pada bak no.1 merupakan bak yang pertama dari limbah pasar kemudian lanjut pada bak 2, 3 dan 4 merupakan bak penyaring dimana menahan material-material yang berat jenisnya lebih berat dan lebih ringan dari pada berat jenis air yang lewat. Dengan adanya penyaringan tersebuat diharapkan dapat mengurangi dan menyerap zat kimia pada air sebelum masuk saluran pembuangan kota.

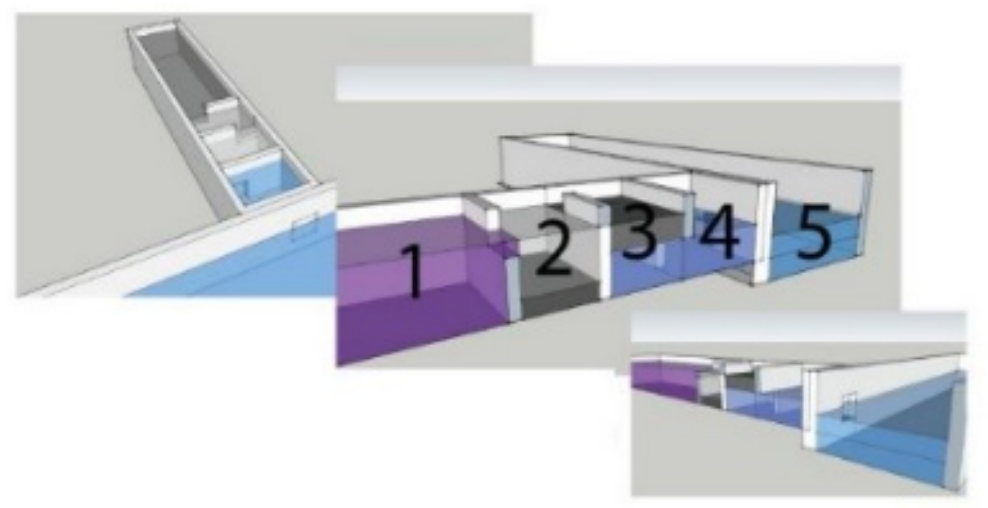

Gambar 20. Penyaringan Air Kotor

\section{c. Alur Pengumpulan Sampah}

Alur pengumpulan sampah pada masing-masing lantai yaitu menuju ruang shaft. Sampah dari ruang shaft selanjutnya dibawa ketempat pembuangan sementara yang berada di belakang bangunan. Seluruh sampah selanjutnya akan diambil oleh petugas kebersihan sampah kota untuk dibawa ke tempat pembuangan akhir.

\section{Material Bangunan}

\section{a. Pelapis Lantai}

Material keramik cocok digunakan pada lantai pasar dimana padatnya aktivitas berjalan dan mengelilingi seluruh area bangunan dengan membawa belanjaan. Dengan tekstur permukaan lantai yang lebih kasar, maka akan mengurangi resiko orang yang bergerak cepat di atasnya tersebut terpeleset atau jatuh, bahkan dapat menambah kecepatan orang yang bergerak di atasnya. Selain itu keramik pada dasarnya juga memiliki sifat mudah dibersihkan sehingga sangat cocok digunakan pada bangunan pasar.

\section{b. Dinding}

Pasangan batu dipilih sebagai dinding, pasangan batu bata adalah bahan batuan yang disusun dengan menggunakan adukan sebagai perekat sehingga membentuk konstruksi bangunan tertentu. Pasangan batu bata disusun sedemikian rupa dengan menggunakan adukan sehingga membentuk konstruksi pada bagian bangunan tertentu.

\section{c. Rangka Atap}

Baja ringan adalah baja berkualitas tinggi yang bersifat ringan dan tipis, akan tetapi kekuatannya tidak kalah dari baja konvensional. Alasan memilih baja ringan antara lain:

- Pemasangan rangka atap baja ringan sangat mudah dan efisien

- Bentukan rangka atap baja ringan bervariasi, bisa dibuat mengikuti berbagai model atap

- Meskipun terbuat dari bahan logam rangka atap baja ringan anti karat

- Dapat digunakan untuk berbagai jenis penutup atap 


\section{d. Pelapis Atap}

Atap Zincalum adalah merupakan material baja dengan pelapisan yang mengandung unsur alumunium dan zinc, terdiri dari: 55\% unsur coatingnya adalah Aluminium, 43,5\% adalah unsur seng/zink dan 1,5\% unsur silikon. Sifat Aluminium yang tahan karat dikombinasikan dengan Zinc yang keras menjadikan kombinasi dari kedua bahan tersebut lebih tahan karat, kuat dan lebih ringan dibandingkan dengan Galvanis. Bahkan beberapa referensi menyatakan bahwa Atap ataupun Rangka Baja Ringan Zincalume Galvalume memiliki ketahanan karat/korosi mencapai 4 kali lipat dibanding baja berlapis Galvanis. Atap zincalum memiliki berbagai variasi yang dapat menyesuaikan bentuk atap yang diinginkan, salah satunya atap lengkung.
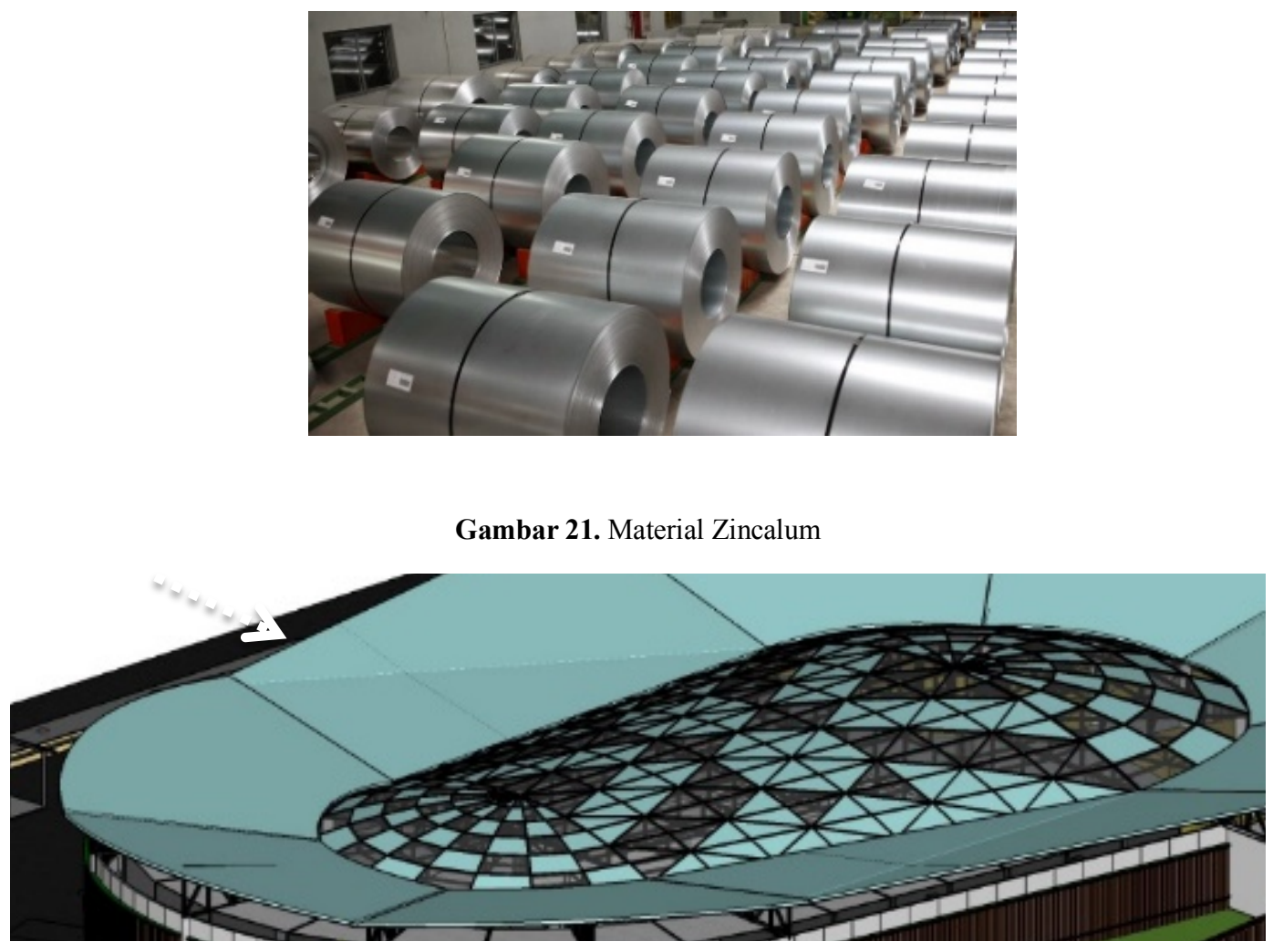

Gambar 22. Material Polikarbonat Pada Atap

Polikarbonat sering juga disebut sebagai engineering plastic yang merupakan hasil sintesa minyak bumi dan gas. Polikarbonat sangat bening dan memiliki kemampuan mentransmisikan cahaya yang sangat baik dibandingkan dengan jenis kaca lainnya. Mudah dipotong dengan peralatan biasa, dibentuk lengkungan, dan mudah pemasangannya. Bahkan Polikarbonat ini telah direkomendasikan sebagai bahan bangunan yang ramah lingkungan. e. Fasad

Pada fasad bangunan lantai satu yaitu dengan material kaca. Kios-kios yang mengelilingi fasad bangunan merupakan kios pakaian, perlengkapan, serta mainan anak. Sehingga material kaca cocok digunakan untuk mengekspos barang dan perlengkapan sebagai daya tarik pembeli.

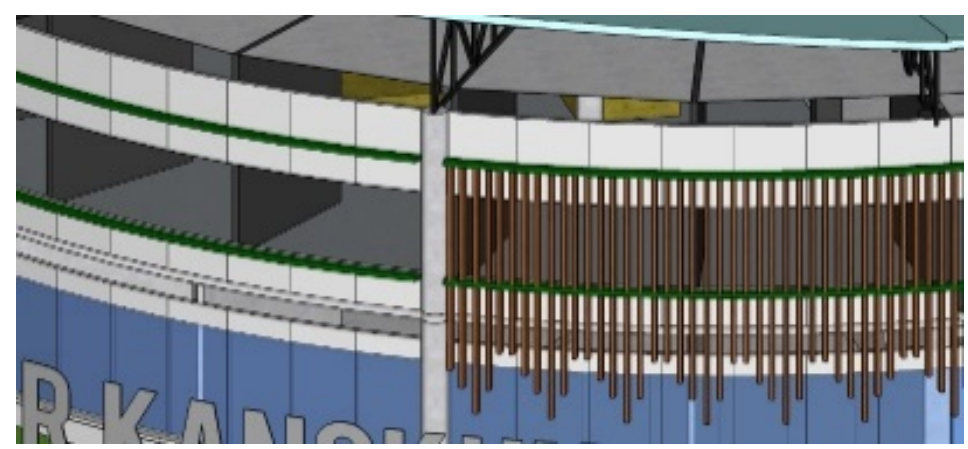

Gambar 23. Material Pada Fasad 
Sedangkan sebagai kisi-kisi yang terletak di sekeliling fasad bangunan digunakan material kayu. Kisi-kisi tersebut menutupi $3 / 4$ bagian dinding pada lantai 2 yaitu pada lantai 2 dinding hanya memiliki ketinggian 1 meter. Selanjutnya dibiarkan sebagai bukaan namun tetap terlapisi atau terlindung oleh kisi-kisi kayu tersebut. Selain pada kisi-kisi, penerapan material kayu juga diterapkan pada ramp penyebrangan. Lapisan kayu digunakan sebagai pelapis permukaan jalan pada ramp. Material kayu dipilih selain bahannya kuat \& tahan lama, juga mampu memberi keindahan pada ramp sehingga para pengunjung pasar mau menggunakan ramp dan tidak menyebrang jalan yang dapat mengakibatkan kemacetan.

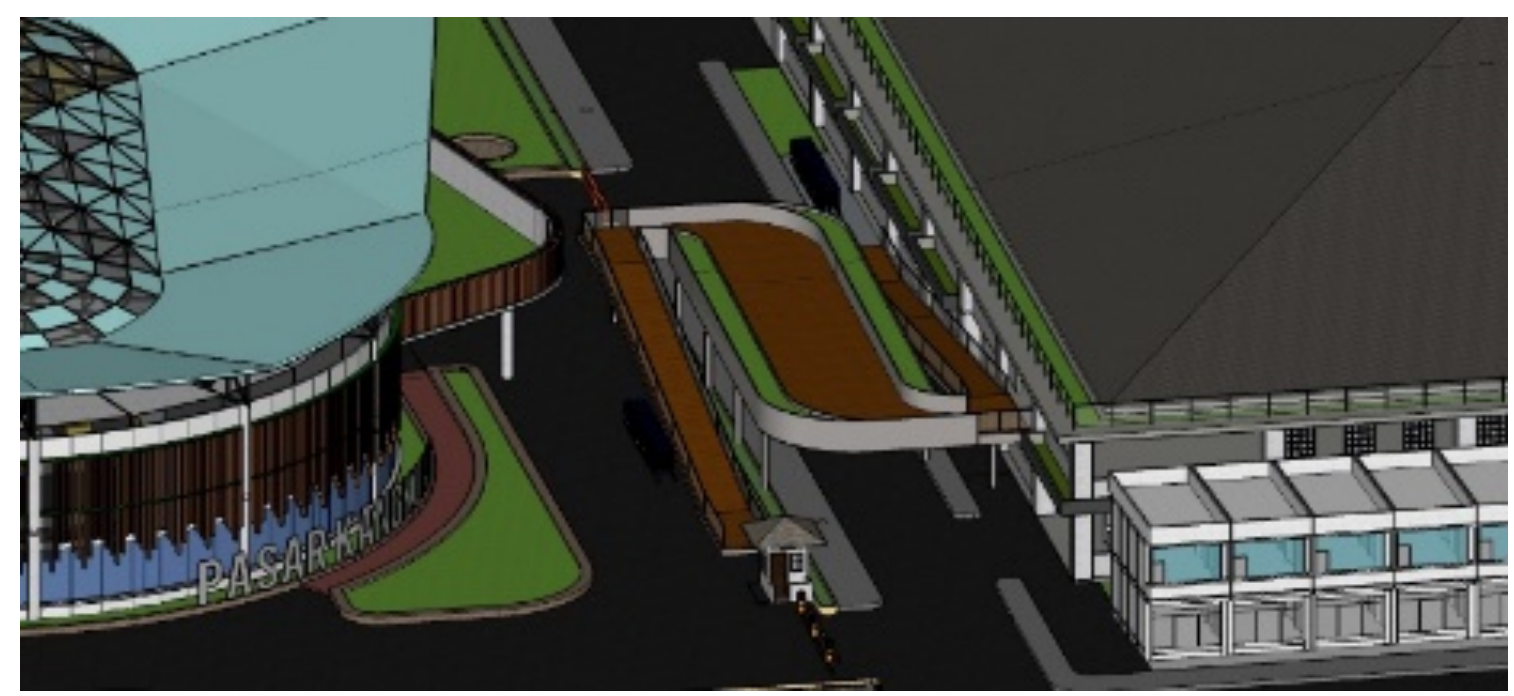

Gambar 24. Ramp

\section{Kesimpulan}

Pada bagian kesimpulan dituliskan temuan penelitian secara ringkas, tanpa tambahan intepretasi baru lagi. Pada bagian ini juga dapat dituliskan kebaruan temuan/diskursus, kelebihan dan kekurangan dari temuan/diskurus, serta rekomendasi untuk penelitian/ diskursus selanjutnya.

\section{Daftar Pustaka}

Adianti, M. M. (2016). Perancangan Pasar Tradisional dengan Konsep Modern. Jurnal Sains dan Seni ITS, 4(2). Agustina, S. (2009). Redesain Pasar Induk Batang (Doctoral dissertation, Jurusan Arsitektur Fakultas Teknik Undip). Neufert, Ernst. 1996. Data Arsitek Edisi 33: Jilid I. Jakarta: Erlangga 